\title{
Pemetaan Komoditas Basis di Kecamatan Polongbangkeng Utara Kabupaten Takalar
}

\author{
Basis Commodities Mapping in Polongbangkeng Utara District, \\ Takalar Regency
}

Muhammad Anshar ${ }^{1}$ dan Irsyadi Siradjuddin ${ }^{1}$

Diterima: 11 November 2020

Disetujui: 14 Desember 2020

\begin{abstract}
Abstrak: Kebijakan pengembangan komoditas di Kecamatan Polongbakeng Utara belum mampu mengoptimalkan potensi sumber daya alamnya. Salah satu upaya untuk optimalisasi potensi tersebut yaitu identifikasi komoditas basis tanaman pangan dengan memetakan potensinya pada setiap desa di Kecamatan Polongbangkeng Utara. Penelitian ini bertujuan untuk mengetahui komoditas pertanian pangan yang merupakan komoditas basis serta membuat pemetaannya di Kecamatan Polongbangkeng Utara. Metode analisis yang digunakan adalah analisis LQ dan pemetaan Ar-GIS. Hasil penelitian menunjukkan bahwa komoditas pertanian pangan yang menjadi komoditas basis di Kecamatan Polongbangkeng utara adalah padi, jagung, kacang hijau, ubi kayu dan ubi jalar. Palleko merupakan desa yang memiliki komoditas basis terbanyak dengan memiliki 4 komoditias basis yaitu padi, kacang hijau, ubi kayu, dan ubi jalar. Komoditi padi dan ubi jalar merupakan komoditas basis terbanyak karena menjadi basis pada 12 desa dari 18 desa di kecamatan Polongbangkeng Utara. Pemetaan komoditas basis dilakukan pada 5 komoditas tanaman pangan. Hasil pemetaan menunjukkan bahwa poligon komoditas non basis (50 poligon) lebih banyak dibanding poligon komoditas basis (40 poligon).
\end{abstract}

Kata Kunci : pemetaan, komoditas basis, tanaman pangan,

Abstract: The policy for commodity development in Polongbakeng Utara District has not been able to optimize its natural resource potential. One of the efforts to optimize this potential is the identification of food crops basis commodities by potential mapping in each village in Polongbangkeng Utara District. This study aims to identify the food crops commodity which is a basis commodity and to make the basis commodities mapping in Polongbangkeng Utara District. The analytical method used is LQ analysis and Ar-GIS mapping. The results showed that the food crops commodities which were the basis commodities in Polongbangkeng Utara District were rice, corn, green beans, cassava and sweet potatoes. Palleko is a village that has the most basis commodities with 4 basis commodities, namely rice, green beans, cassava and sweet potato. Rice and sweet potato commodities are the most basis commodities because they are the basis for 12 villages out of 18 villages in Polongbangkeng Utara district. Base commodity mapping was carried out on 5 food crop commodities. Mapping results show that there are more non-basis commodity polygons (50 polygons) than basis commodity polygons (40 polygons).

Keywords: mapping, basis commodities, food crops.

\footnotetext{
${ }^{1}$ Jurusan Teknik PWK, Fakultas Sains dan Teknologi, UIN Alauddin Makassar
} 


\section{PENDAHULUAN}

Pengembangan kawasan perdesaan tidak kalah penting dibandingkan dengan pengembangan pada kawasan perkotaan, yang secara terintegrasi pengembangan keduanya ditujukan untuk mewujudkan penyelenggaraan penataanruang wilayah nasional yang aman, nyaman, produktif, dan berkelanjutan (Burano, 2017). Upaya dalam peningkatkan perekonomian dengan pemanfaatan komoditas basis disetiap wilayah kecamatan perlu dilakukan dan melihat komoditas basis yang mengalami perubahan peran di masa mendatang, namun belum ada suatu acuan yang akurat dari pemerintah untuk menentukan kebijakan yang sesuai dengan komoditas basis sektor pertanian dan dikembangkan pada suatu wilayah yang memiliki pertumbuhan dan daya saing yang baik, sehingga memberikan nilai tambah yang memadai dan memberikan kontribusi yang tinggi bagi pertumbuhan ekonomi wilayah (Hamsir dan Lamusa, 2019)

Kebijakan pengembangan komoditas basis di Kecamatan Polongbakeng Utara belum banyak dilaporkan mampu meningkatkan kesejahteraan masyarakat dan mengoptimalkan potensi sumber daya manusianya. Menurut (Hildawati, R. Marsuki Iswandi, 2018) Upaya untuk mengetahui kemampuan setiap komoditi yang ada dalam sub sektor pertanian sebagai basis perekonomian suatu daerah dapat dianalisis dengan metode Location Quotient. Kapasitas pasar sektor non basis bersifat belum berkembang atau bersifat lokal. Teori basis ekonomi dinyatakan bahwa dalam suatu daerah terdapat dua sektor kegiatan, yaitu basis dan non basis. Sektor basis adalah sektor yang memiliki potensi besar dalam menentukan pembangunan menyeluruh di daerah, sedangkan sektor non basis merupakan sektor penunjang dalam pembangunan menyeluruh tersebut.

Sebagai upaya untuk pengembangan komoditas basis di Kecamatan Polongbangkeng Utara, perlu dilakukan pemetaan komoditas basis untuk membantu masyarakat fokus mengembangkan komoditas basis yang sesuai dengan kondisi alam dan memiliki nilai ekonomi secara global. Menurut (Sari dan Santoso, 2016) permasalahan pada faktor komoditas basis selama ini karena belum ada pemetaan pemanfaatan hasil produksi komoditas, sehingga petani cenderung menjual mentah hasil produksinya. Berdasarkan kondisi tersebut, perlu penelitian mengenai pemetaan komoditas basis di Polongbangkeng Utara Kabupaten Takalar. Penelitian ini bertujuan untuk menentukan komoditas pertanian yang merupakan komoditas basis di Kecamatan Polongbangkeng Utara dan membuat pemetaan komoditas basis di Kecamatan Polongbangkeng Utara.

\section{METODE}

\section{Jenis dan Sumber Data}

Jenis penelitian yang dilakukan adalah jenis penelitian survey deskriptif kualitatifkuantitatif. Penelitian ini merupakan metode penelitian yang menggambarkan dan menginterpretasikan objek sesuai dengan keberadaan baik deskriptif maupun interpretasi angka. Secara administratif lokasi penelitian ini dilaksanakan di Polongbangkeng Utara Kabupaten Takalar Kecamatan. Penetapan lokasi penelitian didasarkan dengan pertimbangan bahwa Kecamatan Polongbangkeng Utara merupakan sentra pertanian di Kabupaten Takalar. Penelitian dilakukan pada 18 desa di Kecamatan Polongbangkeng Utara Kabupaten Takalar. Penelitian dilaksanakan mulai bulan Mei - September 2020.

\section{Metode Analisis}

Untuk mengetahui komoditas basis di Kecamatan Polongbangkeng Utara menggunakan analisis Location Quotient (LQ). Menurut (Baladina et al., 2013) analisis location quotient (LQ) digunakan untuk mengetahui potensi ekonomi komoditi pertanian di Kecamatan Poncokusumo yang mungkin dikembangkan untuk industrialisasi pertanian. Adapun analisisnya sebagai berikut: 
$L Q=\frac{\mathrm{Ri} / \mathrm{Rt}}{\mathrm{Ni} / \mathrm{Nt}}$

Keterangan :

$\mathrm{Ri}=$ nilai produksi komoditas i kecamatan

$\mathrm{Rt}=$ nilai produksi komoditas total kecamatan

$\mathrm{Ni}=$ nilai produksi komoditas i kabupaten

$\mathrm{Nt}=$ nilai produksi komoditas total kabupaten

Jika nilai $\mathrm{LQ} \geq 1$, maka komoditas tersebut merupakan basis.

Jika nilai $\mathrm{LQ}<1$, maka komoditas tersebut merupakan non basis.

Untuk pemetaan komoditas basis menggunakan hasil analisis Location Quotient yang digambarkan dengan pemetaan menggunakan aplikasi Sistem Informasi Geografis (GIS).

\section{HASIL DAN PEMBAHASAN}

Kecamatan Polongbangkeng Utara merupakan salah satu kawasan strategis pertanian yang ada di Kabupaten Takalar. Secara geografis Ibukota Kecamatan Polongbangkeng Utara adalah Kelurahan Palleko yang berjarak sekitar $10 \mathrm{~km}$ dari Ibukota Kabupaten Takalar dengan batas-batasnya. Prinsip dasar pengembangan kawasan peruntukan pertanian didasari kesesuaian lahan dan persyaratan agroklimat yang dicirikan dengan lokasi budidaya mengacu pada Rencana Tata Ruang Wilayah baik pada lahan basah maupun lahan kering khususnya dalam pengembangan komoditas tanaman pangan. Hasil penelitian menunjukkan bahwa terdapat lima komoditas pangan yang menjadi komoditas basis di Kecamatan Polongbangkeng Utara. Kelima komoditas basis tersebut adalah Padi, Jagung, Kacang Hijau, Ubi Kayu dan Ubi Jalar.

\section{Komoditi Padi}

Komoditi Padi merupakan salah satu komoditas basis di Kecamatan Polongbangkeng Utara. Berdasarkan hasil analisis LQ terdapat 12 desa / kelurahan yang menjadi wilayah basis. Adapun desa / kelurahan tersebut adalah Panrannuangku, Mannongkoki, Malewang, Palleko, Mattopodalle, Parangluara, Pa'rappunganta, Ko'mara, Kampung Beru, Lassang, Parangbado, dan Lassang Barat. Pemetaan komoditi padi sebagai komoditas basis dapat dilihat pada Gambar 1.

Kawasan peruntukan pertanian merupakan kawasan yang diperuntukkan bagi kegiatan pertanian yang meliputi kawasan pertanian lahan basah, kawasan pertanian lahan kering, kawasan pertanian tanaman tahunan/perkebunan, perikanan, peternakan dengan fungsi utama antara lain menghasilkan bahan pangan, palawija, tanaman keras, hasil peternakan dan perikanan, sebagai daerah resapan air hujan untuk kawasan sekitarnya dan membantu dalam penyediaan lapangan kerja bagi masyarakat setempat. Berikut gambar peta komoditi jagung di di Kecamatan Polongbangkeng Utara Kabupaten Takalar. Hal ini didukung oleh penelitian Sitorus et al., (2013) bahwa keunggulan komparatif komoditas tanaman padi sawah memiliki sebaran paling luas dibandingkan komoditas tanaman pangan lain dan diusahakan petani merata di seluruh kota/kabupaten. Lebih lanjut disampaikan oleh Putri et al., (2020) bahwa komoditas basis pada subsektor tanaman pangan adalah komoditas padi sawah. Komoditas padi sawah memiliki keunggulan komparatif dan kompetitif sehingga mampu bersaing dipasar yang lebih luas hingga ke Negara Malaysia. 


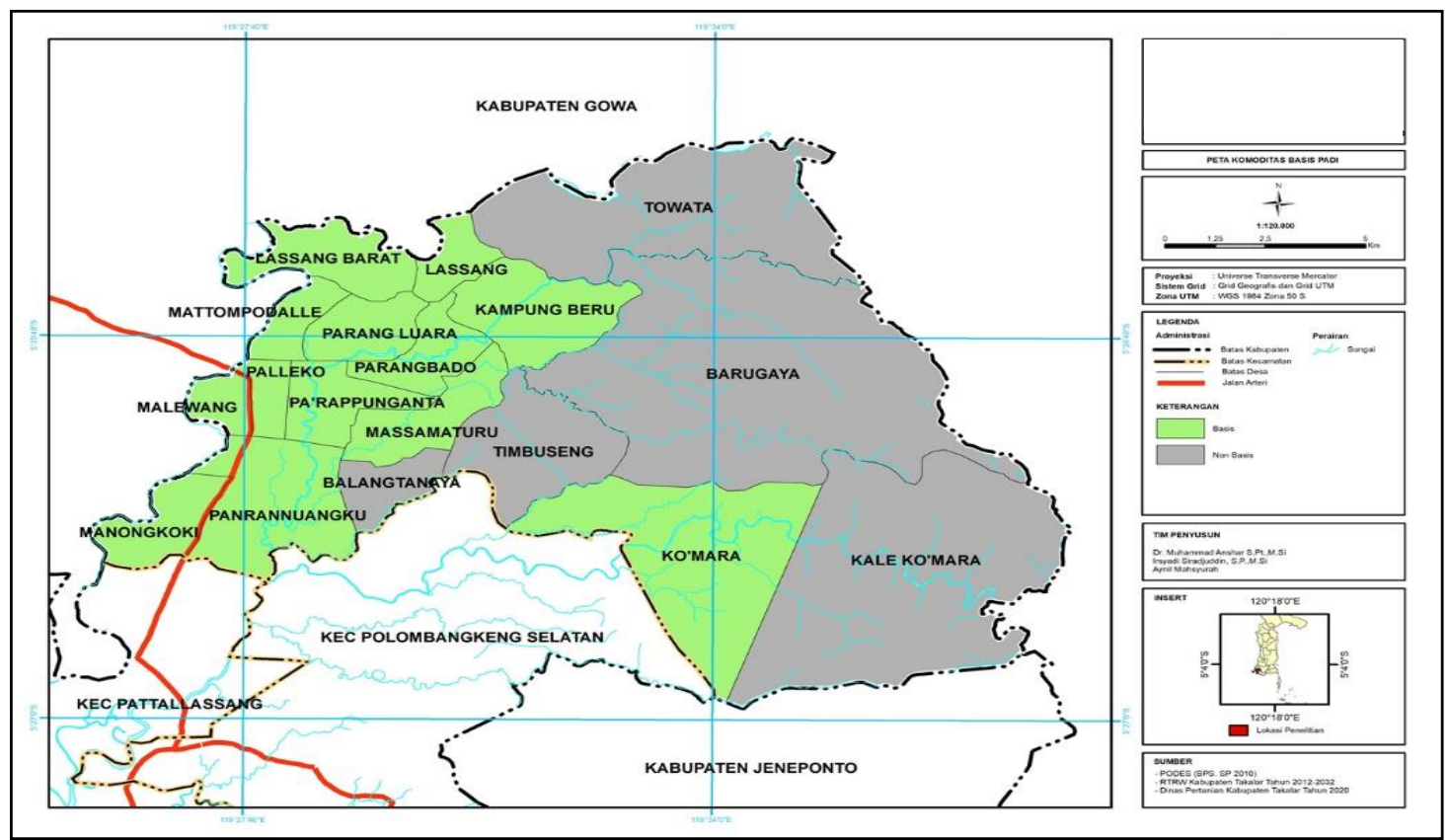

\section{Gambar 1. Peta Komoditas Basis komoditi Padi di Kecamatan Polongbangkeng Utara.}

\section{Komoditi Jagung}

Komoditi Jagung merupakan komoditas basis di Kecamatan Polongbangkeng Utara. Berdasarkan hasil analisis LQ terdapat 7 desa / kelurahan yang menjadi wilayah basis. Adapun desa / kelurahan tersebut adalah Mannongkoki, Malewang, Massamaturu, Timbuseng, Barugaya, Towata, dan Kale Ko'mara. Pemetaan komoditi Jagung sebagai komoditas basis dapat dilihat pada Gambar 2 .

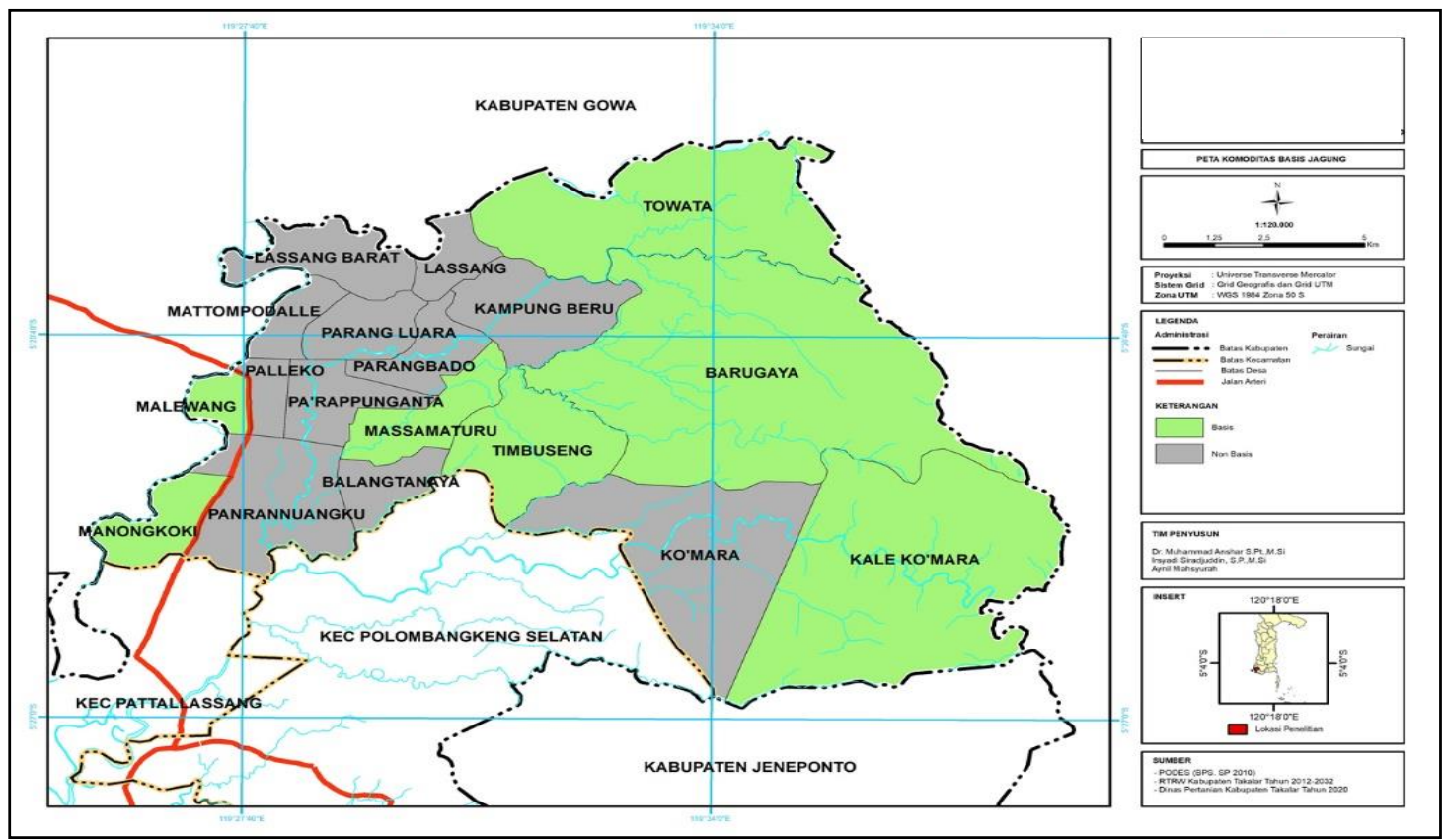

Gambar 2. Peta Komoditas Basis komoditi Jagung di Kecamatan Polongbangkeng Utara. 
Lahan pertanian pangan berkelanjutan adalah lahan yang dikelola untuk budiaya pertanian ramah lingkungan yang mampu mencapai produktivitas dan keuntungan optimal dengan tetap selalu menjaga kelestarian sumberdaya lahan dan lingkungan. Tipologi lahan kawasan berdasarkan kesesuaian lahan untuk tanaman pangan yaitu Dataran rendah dan dataran tinggi, dengan bentuk lahan datar sampai berombak (lereng $<8 \%$ ). Hal ini sejalan dengan Susanto (2014) bahwa jagung merupakan komoditi tanaman bahan pangan yang termasuk dalam klasifikasi komoditi prima (unggulan). Komoditi jagung dikatakan komoditi unggulan karena pertumbuhan komoditinya cepat dan mempunyai kontribusi yang besar. Pertumbuhan komoditinya dikatakan cepat karena laju pertumbuhan dari setiap komoditi tersebut lebih besar dari laju pertumbuhan PDRB. Lebih lanjut Dahoklory (2020) komoditi basis pada subkategori tanaman pangan yaitu komoditi Jagung. Komoditi ini teridentifikasi merupakan komoditi basis karena memberikan kontribusi terbesar dan memiliki peran penting pada subkategori tanaman pangan di Kabupaten Maluku Barat Daya di dibuktikan dengan rata-rata nilai perhitugan LQ Jagung $>1$. Sedangkan Payung dan Paraeng (2020) menyatakan bahwa jagung menjadi komoditas basis karena produksi jagung mampu memenuhi kebutuhan masyarakat di distrik tersebut dan sebagian produksinya di ekspor ke daerah lain. Komoditas ini juga didukung oleh produksi yang cukup banyak, kondisi daerah yang sesuai dengan komoditas jagung, yaitu suhu, dan juga kandungan tanah yang cocok untuk tumbuhnya komoditas jagung.

\section{Komoditi Kacang Hijau}

Komoditi Jagung merupakan komoditas basis di Kecamatan Polongbangkeng Utara. Berdasarkan hasil analisis LQ terdapat 5 desa / kelurahan yang menjadi wilayah basis. Adapun desa / kelurahan tersebut adalah Panrannuangku, Palleko, Mattopodalle, Parangluara, dan Pa'rappunganta. Pemetaan komoditi Kacang Hijau sebagai komoditas basis dapat dilihat pada Gambar 3.

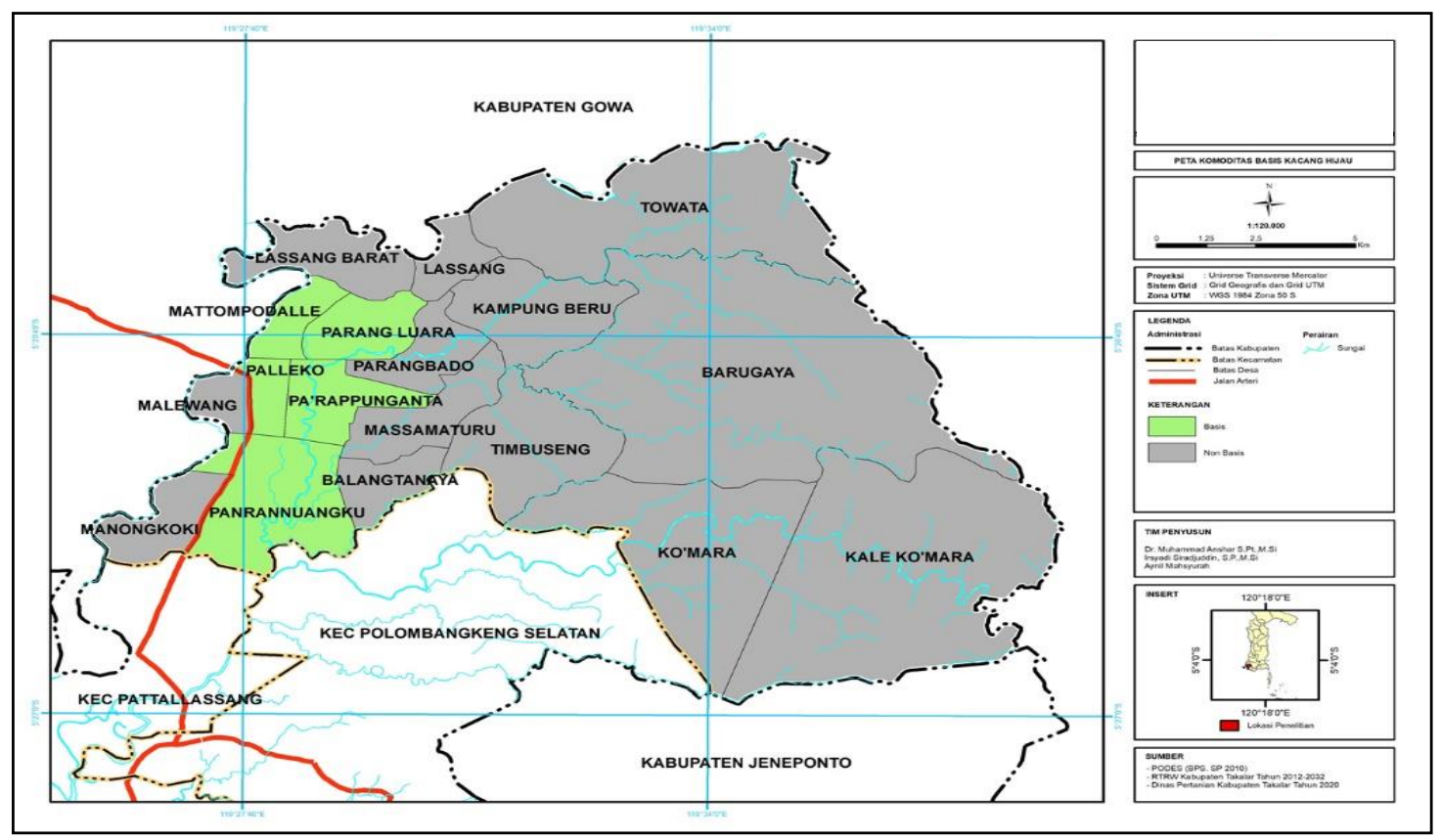

Gambar 3.Peta Komoditas Basis komoditi Kacang Hijau di Kecamatan Polongbangkeng Utara.

Peningkatan kegiatan produksi pangan melalui pemanfaatan lahan pertanian pangan didasarkan pada kesesuaian lahan komoditi Kacang Hijau dalam upaya memperoleh 
bahan pangan komoditas tanaman pangan yang sehat, ekonomis, dan berkelanjutan. Tanaman kacang hijau tergolong basis di 5 desa / kelurahan karena memiliki keunggulan komparatif, hasilnya tidak saja dapat memenuhi kebutuhan di wilayah bersangkutan akan tetapi juga diekspor atau dijual ke luar desa / kelurahan tersebut. Menurut Sitorus et al., (2013) Kacang Hijau menjadi komoditas basis pada 4 kabupaten di Provinsi Lampung karena komoditi ini sebagian besar dapat tumbuh pada lahan Sesuai Marjinal dengan faktor pembatas kemasaman tanah.

\section{Komoditi Ubi Kayu}

Komoditi ubi kayu merupakan komoditas basis di Kecamatan Polongbangkeng Utara. Berdasarkan hasil analisis LQ terdapat 4 desa / kelurahan yang menjadi wilayah basis. Adapun desa / kelurahan tersebut adalah 1. Palleko, 2. Massamaturu, 3. Parangbado, 4. Balangtanaya. Pemetaan komoditi Ubi Kayu sebagai komoditas basis dapat dilihat pada Gambar 4.

Komoditi ubi kayu merupakan komoditi pertanian yang banyak dibudidayakan karena kemudahan penanganannya. Budidaya komoditi ini atas dasar kondisi dan potensi sumber daya alam, sumber daya manusia, dan sumber daya buatan yang memudahkan dalam penumbuhan dan pengelolaan tanamannya. Menurut Faidah et al., (2016) jika nilai LQ lebih besar dari satu artinya kecamatan tersebut merupakan kecamatan basis produksi komoditas ubi kayu karena dapat mengekspor komoditas ubi kayu ke luar kecamatan.

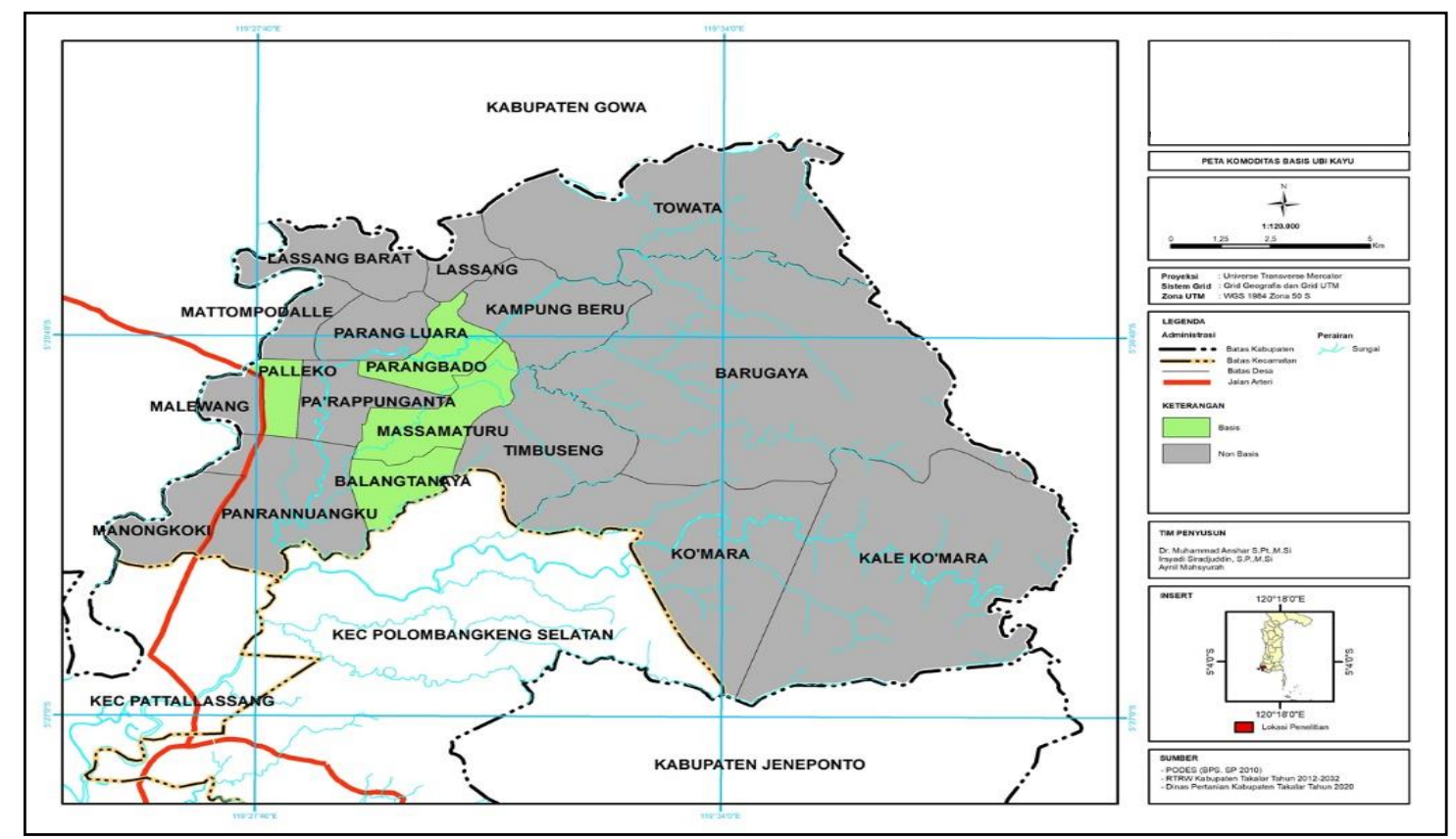

Gambar 4.Peta Komoditas Basis komoditi Ubi Kayu di Kecamatan Polongbangkeng Utara.

\section{Komoditi Ubi Jalar}

Komoditi ubi jalar merupakan komoditas basis di Kecamatan Polongbangkeng Utara. Berdasarkan hasil analisis LQ terdapat 12 desa / kelurahan yang menjadi wilayah basis. Adapun desa / kelurahan tersebut adalah Panrannuangku, Manongkoki, Palleko, Mattopodalle, Parangluara, Pa'rappunganta, Massamaturu, Kampung Beru, Lassang, Parangbado, Lassang Barat, dan Balangtanaya. Pemetaan komoditi Ubi Jalar sebagai komoditas basis dapat dilihat pada Gambar 5. 


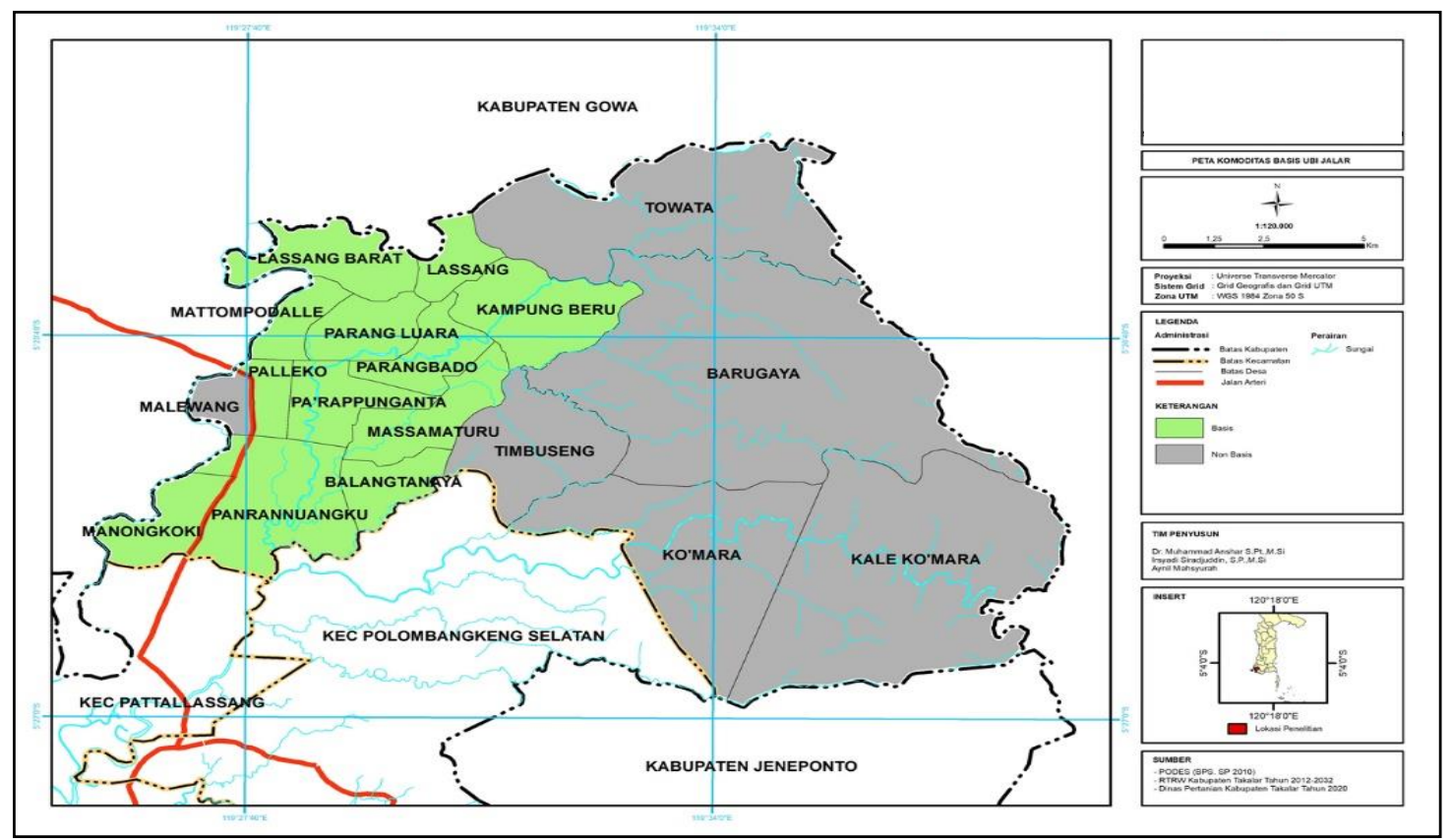

Gambar 5.Peta Komoditas Basis komoditi Ubi Jalar di Kecamatan Polongbangkeng Utara.

Ubi jalar dibudidayakan untuk dimanfaatkan akarnya yang membentuk umbi. Ubi jalar memiliki kadar gizi (karbohidrat) yang tinggi. Masyarakat di Kecamatan Polongbangkeng Utara memanfaatkan umbi ubi jalar sebagai komoditi pangan olahan dan daun mudanya sebagai sayuran. Penentuan ubi jalar sebagai komoditas basis didukung oleh (Keratorop et al., 2016) bahwa pengembangan komoditas basis tanaman pangan di Kabupaten Boven Digoel diarahkan pada komoditi ubi jalar karena memiliki hasil LQ $>1$ pada 10 distrik.

Terdapat lima komoditas basis tanaman pangan yang dibudidayakan oleh masyarakat di Kecamatan Polongbangkeng Utara. Lima komoditas tersebut adalah Padi, Jagung, Kacang Hijau, Ubi Kayu, dan Ubi Jalar. Berdasarkan hasil penelitian, total produksi masing-masing komoditas pada periode 2015 sampai dengan 2019 adalah 187.866,45 ton, $58.700,26$ ton, $1.746,14$ ton, $11.590,74$ ton, dan 13.100,02 ton. Menurut (Balirante et al., 2020) bahwa komoditas unggulan merupakan komoditas yang memiliki nilai strategis berdasarkan pertimbangan fisik, sosial ekonomi, dan kelembagaan untuk dikembangkan di suatu wilayah.

Tabel 1. Hasil Analisis Komoditas Basis di Kecamatan Polongbangkeng Utara.

\begin{tabular}{rllllll}
\hline No & $\begin{array}{c}\text { Desa / } \\
\text { Kelurahan }\end{array}$ & \multicolumn{1}{c}{ Padi } & Jagung & $\begin{array}{c}\text { Kacang } \\
\text { Hijau }\end{array}$ & Ubi Kayu & Ubi Jalar \\
\hline 1 & Panrannuangku & $1,24^{*}$ & 0,25 & $4,66^{*}$ & 0,08 & $1,10^{*}$ \\
2 & Mannongkoki & $1,12^{*}$ & $1,09^{*}$ & 0,32 & 0,27 & $1,22^{*}$ \\
3 & Malewang & $1,14^{*}$ & $1,15^{*}$ & 0,8 & 0,16 & 0,73 \\
4 & Palleko & $1,11^{*}$ & 0,45 & $1,67^{*}$ & $1,85^{*}$ & $2,38^{*}$ \\
5 & Mattopodalle & $1,26^{*}$ & 0,28 & $1,03^{*}$ & 0,03 & $1,78^{*}$ \\
6 & Parang Luara & $1,15^{*}$ & 0,87 & $2,06^{*}$ & 0,86 & $1,42^{*}$ \\
7 & Pa'rappunganta & $1,03^{*}$ & 0,82 & $2,33^{*}$ & 0,66 & $1,02^{*}$ \\
8 & Massamaturu & 0,64 & $1,17^{*}$ & 0,02 & $3,33^{*}$ & $1,85^{*}$ \\
9 & Timbuseng & 0,95 & $1,07^{*}$ & 0,47 & 0,48 & 0,99 \\
10 & Ko'mara & $1,03^{*}$ & 0,95 & 0,21 & 0,81 & 0,42 \\
11 & Barugaya & 0,84 & $1,65^{*}$ & 0,96 & 0,14 & 0,17 \\
\hline
\end{tabular}




\begin{tabular}{cllllll}
\hline No & \multicolumn{1}{c}{$\begin{array}{c}\text { Desa / } \\
\text { Kelurahan }\end{array}$} & \multicolumn{1}{c}{ Padi } & Jagung & $\begin{array}{c}\text { Kacang } \\
\text { Hijau }\end{array}$ & Ubi Kayu & Ubi Jalar \\
\hline 12 & Towata & 0,90 & $1,51^{*}$ & 0,57 & 0,3 & 0,77 \\
13 & Kampung Beru & $1,16^{*}$ & 0,43 & 0,05 & 0,98 & $1,21^{*}$ \\
14 & Lassang & $1,19^{*}$ & 0,67 & 0,15 & 0,12 & $1,48^{*}$ \\
15 & Parangbado & $1,21^{*}$ & 0,22 & 0,19 & $1,21^{*}$ & $1,40^{*}$ \\
16 & Lassang Barat & $1,19^{*}$ & 0,16 & 0,03 & 0,62 & $2,52^{*}$ \\
17 & Balangtanaya & 0,59 & 0,67 & 0,47 & $9,10^{*}$ & $1,14^{*}$ \\
18 & Kale Ko'mara & 0,79 & $2,09^{*}$ & 0,00 & 0,17 & 0,20 \\
\hline
\end{tabular}

* Komoditas Basis.

Berdasarkan tabel 1 bahwa Palleko merupakan kelurahan dengan komoditas basis terbanyak. Adapun komiditi tersebut adalah padi, kacang hijau, ubi kayu, dan ubi jalar. Produksi keempat komoditas ini surplus dan menjadi komoditi ekspor yang meningkatkan ekonomi petani komoditasnya. Menurut Paramartha et al., (2017) bahwa Komoditas unggulan sektor pertanian yang menjadi penggerak perekonomian berdasarkan nilai produksi adalah komoditas tanaman pangan. Sedangkan Kale Ko'mara merupakan desa dengan komoditas basis paling sedikit. Adapun komoditi tersebut adalah jagung. Menurut Ameliya et al., (2020) bahwa walaupun luas lahan, produktivitas dan produksinya menurun akan tetapi jika masih konsisten berusaha pada komoiditas tersebut maka masih bisa mencukupi kebutuhan wilayahnya terlebih lagi jika dilakukannya intensifikasi.

Komoditi padi dan ubi jalar merupakan komoditas basis terbanyak di Kecamatan Polongbangkeng Utara. Komoditi ini menjadi basis pada 12 desa / kelurahan dari total 18 desa / kelurahan di Kecamatan Polongbangkeng Utara. Kedua komoditas ini diduga mengalami kenaikan permintaan dan peningkatan produksi. Hasil penelitian Pratama (2020) menunjukkan bahwa komoditas Jagung, Ubi kayu, Ubi Jalar, Kacang Tanah dan Kedelai memiliki angka LQ> 1 . Hasil ini menggambarkan lima produk ini menjadi produk basis di Kabupaten Kebumen.

Pemetaan komoditas basis pada Kecamatan Polongbangkeng Utara dilakukan pada 5 komoditas tanaman pangan. Hasil pemetaan menunjukkan bahwa poligon komoditas non basis (50 poligon) lebih banyak dibanding poligon komoditas basis (40 poligon). Urutan poligon komoditas basis dari yang terbanyak sampai paling sedikit yaitu padi, ubi jalar, jagung, kacang hijau, dan ubi kayu. Masing-masing poligon komoditas basisnya yaitu 12, 12, 7, 5, dan 4 poligon. Menurut Jauhari (2020) bahwa penggunaan GIS berfungsi untuk mengolah data spasial dan data statistik menjadi peta. Pemetaan komoditas sebagai dasar pengambilan keputusan penentuan kawasan komoditas tanaman pangan. Hasil pemetaan menjadi masukkan dan evaluasi bagi kebijakan yang dicanangkan pemerintah daerah untuk mengembangkan kawasan agropolitan serta pengembangan sarana dan prasarana pendukungnya.

\section{KESIMPULAN}

Komoditas pertanian pangan yang menjadi komoditas basis di Kecamatan Polongbangkeng utara adalah padi, jagung, kacang hijau, ubi kayu dan ubi jalar. Palleko merupakan desa yang memiliki komoditas basis terbanyak dengan memiliki 4 komoditias basis yaitu padi, kacang hijau, ubi kayu, dan ubi jalar. Komoditi padi dan ubi jalar merupakan komoditas basis terbanyak karena menjadi basis pada 12 desa dari 18 desa di kecamatan Polongbangkeng Utara.

Pemetaan komoditas basis dilakukan pada 5 komoditas tanaman pangan. Hasil pemetaan menunjukkan bahwa poligon komoditas non basis (50 poligon) lebih banyak dibanding poligon komoditas basis (40 poligon). 


\section{DAFTAR PUSTAKA}

Ameliya, I., Anzitha, S., \& Saragih, F. H. (2020). Analisis Location Quotient (LQ) Padi di Kota Langsa. Mediagro Jurnal Ilmu-Ilmu Pertanian, 16(1), 60-67.

Baladina, N., Anindita, R., Isaskar, R., \& Sukardi. (2013). Identifikasi Potensi Komoditi Pertanian Unggulan dalam Penerapan Konsep Agropolitan di Kecamatan Poncokusumo, Kabupaten Malang. AGRISE, XIII(1), 30-41.

Balirante, N., Sendow, M. M., \& Porajouw, O. (2020). Identifikasi komoditas pertanian pangan, palawija dan hortikultura unggulan di kecamatan tompaso barat kabupaten minahasa. AGRIRUD, 2(2), 87-92.

Burano, R. S. (2017). Pengembangan Kawasan Pedesaan Berkelanjutan Berbasis Pertanian Lahan Basah. Jurnal Pertanian Faperta UMSB, 1(1), 25-34.

Dahoklory, A. S. K. (2020). Analisis Potensi Wilayah Sektor Pertanian Di Kabupaten Maluku Barat Daya. 1(September), 64-69.

Faidah, A., Hapsari, T. D., \& Januar, J. (2016). Analisis Wilayah Komoditas Ubi Kayu dan Kontribusinya terhadap Sektor Pertanian di Kabupaten Pacitan. Jsep, 9(1), 43-62. jurnal.unej.ac.id

Hamsir, H. M., \& Lamusa, A. (2019). Analisis Komoditas Basis Sub Sektor Tanaman Pangan Di Kecamatan Buko Selatan Kabupaten Banggai Kepulauan. J. Agroland, 26(April), 76-85.

Hildawati, R. Marsuki Iswandi, S. (2018). Analisis Komoditas Basis Dan Non Basis Sub Sektor Peternakan. Jurnal Ilmiah Agribisnis, 3(1), 7-11.

Jauhari, A. (2020). Pemanfaatan SIG untuk Pemetaan Kawasan Produksi Komoditas Unggulan Tanaman Pangan di Kabupaten Pacitan. Journal of Regional and Rural Development Planning, 4(3), 154-171. https://doi.org/http://dx.doi.org/10.29244/jp2wd.2020.4.3.154-171

Keratorop, M., Widiatmaka, \& Suwardi. (2016). Development Direction of Comodities Crops in Boven Digoel Regency Papua Province. Jurnal Pengelolaan Sumberdaya Alam Dan Lingkungan, 6(2), 141-150. https://doi.org/10.19081/jpsl.2016.6.2.141

Paramartha, G. Y., Sukaatmadja, I. P. G., \& Sri Astiti, N. W. (2017). Penentuan Komoditas Unggulan Pertanian Berdasarkan Nilai Produksi Di Kabupaten Buleleng. JURNAL MANAJEMEN AGRIBISNIS (Journal Of Agribusiness Management), 5(2), 43-48. https://doi.org/10.24843/jma.2017.v05.i02.p07

Payung, S. E. T., \& Paraeng, S. (2020). Analisis Komoditas Unggulan Sub Sektor Tanaman Pangan dan Arah Pengembangannya di Kabupaten Mimika. JURNAL KRITIS (Kebijakan, Riset, Dan Inovasi), 4(1), 89-109.

Pratama, M. P. (2020). Analisis dan Kontribusi Sektor Basis Non-Basis: Penentu Potensi Produk Unggulan Kabupaten Kebumen. Jurnal Ilmiah Akuntansi Dan Keuangan, 9(1), 75-82. https://doi.org/10.32639/jiak.v9i1.313

Putri, D. S. H., Hernovianty, F. R., \& Yuniarti, E. (2020). Analisis komoditas unggulan berbasis pertanian di kecamatan sekadau hilir, kabupaten sekadau 1. JeLAST : Jurnal Elektronik Laut, Sipil, Tambang, 7(2), 16.

Sari, D. A. W., \& Santoso, E. B. (2016). Faktor-faktor yang Mempengaruhi Pengembangan Komoditas Unggulan Hortikultura di Kawasan Agropolitan Ngawasondat Kabupaten Kediri. JURNAL TEKNIK ITS, 5(1), 64-69.

Sitorus, S. R. P., Widodo, B. W., \& Panuju, D. R. (2013). Identifikasi Komoditas Basis Tanaman Pangan Dan Arahan Pengembangannya Di Provinsi Lampung. Jurnal Ilmu Tanah Dan Lingkungan, 15(1), 29. https://doi.org/10.29244/jitl.15.1.29-38

Susanto, H. (2014). Kajian Komoditas Unggulan, Andalan Dan Potensial Di Kabupaten Grobogan. Journal of Rural and Development, $V(1), 63-80$. 